\title{
Vernacular Deconstruction: Undermining Spin
}

(Desconstrução Vernacular: Subscrevendo a Leitura Propalada)

\author{
J. R. MARTIN \\ (Linguistics, University of Sydney)
}

\begin{abstract}
This paper is concerned with the way in which three popular culture texts are deployed to challenge discourse which naturalises war. Each text mobilises ideational resources to draw attention to the material cost of war and interpersonal resources to realign reader/viewers into peace seeking communities; in addition, each text deploys dramatic shifts in semiosis to re-focus reader/viewers' understanding and evaluation of armed struggle. The analysis is offered as a contribution to the field of positive discourse analysis and its interpretation of texts which function to make the world a better place. KEY-WORDS: positive discourse analysis; discourse analysis; systemic functional grammar; interepersonal; ideational.
\end{abstract}

RESUMO: Este artigo trata da forma como três textos da cultura popular são construidos para desafiar o discurso que naturaliza a guerra. Cada texto mobiliza recursos ideacionais para chamar a atenşão para o custo material da guerra e recursos interpessoais para realinhar os leitores/observadores em comunidades que buscam a paz. Além disso, os textos constroem deslocamentos semióticos abruptos para mudar a compreensão e a avaliaşão dos leitores/observadores sobre a luta armada. Essa análise é oferecida como uma contribuição ao campo da análise do discurso positiva e à sua interpretaçãa dos textos que têm como função transformar o mundo em um lugar melhor.

PALAVRAS-CHAVE: Analise de discurso positiva; análise de discurso; análise sistêmico funcional; interpessoal; ideacional.

\section{War and peace}

Events of the noughts have naturally focussed the attention of critical discourse analysts on the discourse of war, especially the rhetoric used by political leaders to legitimise military engagements. Volume 15.2/3 of Discourse \& Society, for example (Edwards \& Martin 2004), addresses the 
aftermath of 9/11, including extensive discussion of Bush, Blair and Howard's 'war on terror' and 'regime change' in Iraq. Interestingly, while some of these contributions consider discourse that is critical of the 'coalition of the willing', there is little consideration of the extensive discourse of peace $^{1}$ enacted in resistance to the coalition's stance. And it is by no means clear how the various scholarly deconstructions offered can be mobilised $^{2}$ against war-mongering spin in the community at large. The analyses are meta-discursive, and so don't contribute directly to the struggle against war in popular culture.

This raises the important issue of how activists mobilise to give peace a chance, using the discourses of popular culture, where the power to influence masses of people resides. I'll pursue this here with respect to three $20^{\text {th }}$ century texts which try and open people's eyes to the material reality of war and re-align them into communities that choose peaceful rather than violent resolutions of conflict. Each text features ideational resources which recontextualise legitimations of war as matters of flesh and blood, and interpersonal resources which negotiate alternative evaluations of the personal cost of sending our sons and daughters to kill and be killed. I'll draw on systemic functional linguistics to explore these ideational and interpersonal resources (Kress \& van Leeuwen 1996, Halliday \& Matthiessen 1999, 2004, Martin \& Rose 2003, Martin \& White 2005), and I offer the discussion as a contribution to what I have called (e.g. Martin 2004) 'positive discourse analysis', which complements CDA by focussing on discourses that are designed to make the world a better place (alongside the more traditional concern of CDA with discourses in the service of the abusive power).

\section{U2 and the troubles in Ireland}

The first text to be considered is an exhortation by the U2 lead singer Bono, included in a performance of the song 'Sunday Bloody Sunday' in

\footnotetext{
Leudar 2004, in this volume, considers a response to the coalition by the Mothers of the Plaza de Mayo at the end of one of their weekly marches in protest at the disappearance of their children during the military dictatorship in Argentina; but the thematics of the special issue prevent her from considering the impact of their protests over the years.

2 For exemplary work translating linguistic analysis of this kind into popular culture see Lukin's archive of interventions at http://www.ling.mq.edu.au/clsl/reporting_war.htm (then click in the news').
} 
America on November 8, 1987 (the song was originally released in 1983 on their War album). Bono introduces the song as follows, by way of underscoring its special poignancy for the band that day - when a bomb exploded during a Remembrance Day service at Enniskillen in County Fermanagh, killing 11 people and wounding at least 63,9 of them seriously. ${ }^{3}$

[1] Well, here we are, the Irish in America. The Irish have been coming to America for years, going back to the great famine when the Irish were on the run from starvation and a British government that couldn't care less... You know there are more Irish immigrants here in America today than ever - some illegal,some legal. A lot of them are just running from high unemployment. Some run from the troubles in Northern Ireland - from the hatred of the H-blocks; others from wild acts of terrorism like we had today in Enniskillen, where 11 people lie dead and many more injured on Sunday, bloody Sunday.

The song itself deals with the 'troubles' in Ireland, and refers in its title, 'Sunday Bloody Sunday', to the events of January 30, 1972, in Derry. On that day, a Northern Ireland Civil Rights Association march of 20,000 people took place to protest against the continuation of internment without trial. Soldiers of the British Parachute Regiment moved into the Bogside and during the next 30 minutes shot dead 13 men (and shot and injured a further 13 people), mainly by single shots to the head and trunk.

The song begins as a slow ballad, with verses reviewing television images of the violence in Ireland. Then, after singing the song's choruses, Bono quiets the band, moves to the left of the stage and speaks to his huge adoring audience as follows:

[2] Let me tell you something. I've had enough of Irish Americans who haven't been back to their country in 20 or 30 years, come up to me and talk about the resistance, the revolution back home, and the glory of the revolution, and the glory of dying for the revolution. Fuck the revolution! They don't talk about the glory of killing for the revolution. What's the glory in taking a man from his bed and gunning him down in front of his wife and children? Where's the glory in that? Where's the glory in bombing a remembrance Day parade of old age pensioners, their medals taken out and polished up for the day. Where's the glory in that? To leave them dying or crippled for life or dead under the rubble of the revolution that the majority of the people in my country don't want.

\footnotetext{
3 On Remembrance Day 1997 the leader of the IRA's political wing, Gerry Adams, formally apologised for the bombing.
} 
No more.Say "No more."

No more. - No more.

No more. - No more.

No more.- No more.

No more. - No more. ...

He then returns to centre stage to complete the song, which assumes a loud martial rock ' $n$ roll rhythm.

Like the other texts we'll consider, Bono's rap develops a concrete materialisation of the discourse legitimising violence he is objecting to. Basically this involves taking the nominalisations resistance and revolution and reworking them as congruent action processes directly affecting people. This process of reformulation is outlined in Table 1, with the legitimating nominalisations on the left and their experiential reconstrual on the right. Note how the right hand column replaces abstractions with concrete processes of dying, killing, gunning down, bombing, crippling and leaving for dead, and includes the men, women and children, and old age pensioners affected.

Table 1: Unpacking legitimising nominalisation in Bono's rap

\begin{tabular}{|l|l|}
\hline $\begin{array}{l}\text { legitimating } \\
\text { nominalisation }\end{array}$ & experiential reconstrual \\
\hline the resistance & \\
\hline the revolution back home & \\
\hline the revolution & {$[$ dying] } \\
\hline$[\mathrm{x}]$ for the revolution & {$[$ killing] } \\
\hline the revolution & $\begin{array}{l}\text { taking a man from his bed and gunning him down } \\
\text { in front of his wife and children }\end{array}$ \\
\hline$[y]$ for the revolution & that (presuming previous row) \\
\hline & $\begin{array}{l}\text { bombing a remembrance Day parade of old age } \\
\text { pensioners, their medals taken out and polished } \\
\text { up for the day }\end{array}$ \\
\hline & that (presuming previous row) \\
\hline & $\begin{array}{l}\text { To leave them dying or crippled for life or dead } \\
\text { under the rubble of the revolution that the majority } \\
\text { of the people in my country don't want. }\end{array}$ \\
\hline
\end{tabular}


Interpersonally the rap involves re-evaluation, drawing on the resources ${ }^{4}$ of appraisal, speech function and mood. Bono's goal here is to undo a positive appreciation of the resistance/revolution as glorious. He begins by expressing negative affect - first towards Irish immigrants appreciating the resistance/revolution as glorious (I've had enough), and then towards the revolution itself (fuck the revolution). Reversing polarity and agency, he notes that people don't talk about the glory of killing for he revolution, sarcastically colligating glory with killing (and thereby in effect disassociating the positive appreciation). He then continues with a series of rhetorical questions, which in effect deny the association of glory with the revolution, and which invoke horror by means of the experiental reconstruals just reviewed. This re-evaluation process is outlined in Table 2.

Table 2: Re-evaluation of the revolution in Bono's rap

\begin{tabular}{|l|l|}
\hline $\begin{array}{l}\text { revolution naturalised as } \\
\text { glorius }\end{array}$ & \& re-evaluated as horrible \\
\hline $\begin{array}{l}\text { the resistance, the } \\
\text { revolution back home, }\end{array}$ & l've had enough \\
\hline $\begin{array}{l}\text { and the glory of the } \\
\text { revolution, }\end{array}$ & \\
\hline $\begin{array}{l}\text { and the glory of dying for } \\
\text { the revolution. }\end{array}$ & \\
\hline & Fuck the revolution! \\
\hline & $\begin{array}{l}\text { They don't talk about the glory of killing for the } \\
\text { revolution }\end{array}$ \\
\hline & $\begin{array}{l}\text { What's the glory in taking a man from his bed and } \\
\text { gunning him down in front of his wife and children? }\end{array}$ \\
\hline & Where's the glory in that? \\
\hline & $\begin{array}{l}\text { Where's the glory in bombing a remembrance Day } \\
\text { parade of old age pensioners, their medals taken out } \\
\text { and polished up for the day? }\end{array}$ \\
\hline & Where's the glory in that? \\
\hline & $\begin{array}{l}\text { To leave them dying or crippled for life or dead under } \\
\text { the rubble of the revolution that the majority of the } \\
\text { people in my country don't want. }\end{array}$ \\
\hline & No more.... - No more... \\
\hline
\end{tabular}

4 The appraisal analysis used in this paper is based on Martin \& White 2004, the speech function and mood analysis on Martin 1992. 
Co-ordinating this re-evaluation is Bono's rhetoric of speech function and mood. He begins with an invitation to his rap (Let me tell you something.), and proceeds to give information about his feelings (I've had enough... and Fuck the revolution!), and then gives some more information about what people don't talk about - the glory (sic) of killing for the revolution. He then engages the audience with four rhetorical questions, for which the literal answer must be None, then Nowhere. Bono concludes with a non-finite non-negotiable clause, (arguably eliding Where's the glory in...), which includes a contentious embedded clause about the wishes of the Irish as far as 'revolution' is concerned. The sequence of choices for grammatical mood (first) and discourse semantic speech function (second, in italics) is listed below:

[imperative; offer]

Let me tell you something.

[declarative; statement]

I've had enough of Irish Americans who haven't been back to their country in 20 or 30 years, come up to me and talk about the resistance, the revolution back home, and the glory of the revolution, and the glory of dying for the revolution.

[imperative; exclamation]

Fuck the revolution!

[declarative; statement]

They don't talk about the glory of killing for the revolution.

[wh interrogative; statement]

What's the glory in taking a man from his bed and gunning him down in front of his wife and children?

Where's the glory in that?

Where's the glory in bombing a remembrance Day parade of old age pensioners, their medals taken out and polished up for the day.

Where's the glory in that?

[non-finite]

To leave them dying or crippled for life or dead under the rubble of the revolution that $[[$ the majority of the people in my country don't $]]$ want.

Monologue then gives way to dialogue, as Bono leads the audience in a call and response 'No War' chant; they of course comply, screaming out 
'No More!' Bono's body language ${ }^{5}$ conducts the crowd, as outlined in parentheses below:

[minor, command]

No more.

(clenching fist, facing front)

[imperative, command]

Say "No more."

(arm raising mike, facing front)

[minor; command, Initiation ${ }^{\wedge}$ Response]

No more.

(moving to face back)

- No more.

(arm raising mike, facing back)

[minor; command, Initiation ^ Response]

No more.

(body down, facing back)

- No more.

(body up \& moving to face front)

[minor; command, Initiation ${ }^{\wedge}$ Response]

No more.

(body up, facing front)

- No more.

(body down, facing front)

[minor; command, Initiation ^ Response]

No more.

(body up, facing front)

- No more.

(body $1 / 2$ down, facing front)

Bono's realignment strategy here is interactive, taking advantage of the immediacy of his engagement with the live audience and his power to control them. His fans are variously positioned to implicitly accept his offer of news, sympathise with his feelings of frustration and anger, and reappraise the revolution; they're then positioned to explicitly vocalise their alignment with his call for an end to terrorism. Basically, as a fan, you have no choice but to comply. You're present after all to belong, and the enthralling power of the musical performance cannot help but sweep you into the fold.

\footnotetext{
There is of course a great deal to say about the various modalities of communication involved in this performance, which we are ignoring at our peril here; Cranny-Francis \& Martin 1991 open up discussion in this arena.
} 


\section{Mark Twain and the Ant-Imperialist League}

The violence negotiated in Bono's song has its roots in the gestation of the English Empire, and the invasion and colonisation of Ireland by 'British' forces. Let's turn now to the beginning of another empire, with the United States annexing Spanish colonies during and at the close of the Spanish-American War. Within America, the Anti-Imperialist League (1998-1921) was established to protest these developments, which were seen as out of step with that nation's ideals. Mark Twain was one of the key spokesmen for this organisation. In order to establish control over the Philippines, America had to defeat the Filipino army which had been fighting for independence against the Spanish since 1896 and abolish the newly formed Philippine Republic. Officially this war ${ }^{6}$ was fought from 1899-1902, with sporadic fighting continuing long afterwards. Mark Twain was a leading critic of this imperialist betrayal of Philippine nationalism and democracy.

Drawing on his literary talents, Twain drafted a timely intervention entitled 'The War Prayer', which was rejected for publication by Harper's Bazaar; it was eventually published after his death by Harper's Monthly, in 1916, when it would have been read in relation to America's involvement in WWI. In his story, Twain imagines a church service on the eve of war, with prayers and hymns invoking victory - for soldiers fighting with God on their side. Of particular interest here is the martial dream (highlighted in [3] below) which Twain constructs for the young volunteers. As with the Irish immigrants discussed above, positive appreciation (glory) is mapped onto a nominalised spin which glosses over the material reality of what the soldiers will in fact experience.

[3] It was a time of great and exalting excitement. The country was up in arms, the war was on, in every breast burned the holy fire of patriotism; ... in the churches the pastors preached devotion to flag and country, and invoked the God of Battles beseeching His aid in our good cause in outpourings of fervid eloquence which moved every listener. It was indeed a glad and gracious time, and the half dozen rash spirits that ventured to disapprove of the war and cast a doubt upon its righteousness straightway got such a stern and angry warning that for their personal safety's sake they quickly shrank out of sight and offended no more in that way.

\footnotetext{
6 The first I learned of this canonical betrayal of democratic nationalist interests was when I was working on Bloomfield's Tagalog Texts, one of which was entitled, 'Fleeing from the Americans'; schooled in North America, I had been raised with a far more naturalised profoundly ignorant view of what went on.
} 
Sunday morning came - next day the battalions would leave for the front; the church was filled; the volunteers were there, their young faces alight with martial dreams - visions of the stern advance, the gathering momentum, the rushing charge, the flashing sabers, the flight of the foe, the tumult, the enveloping smoke, the fierce pursuit, the surrender! Then home from the war, bronzed heroes, welcomed, adored, submerged in golden seas of glory! ... The service proceeded; ...

Then came the "long" prayer. None could remember the like of it for passionate pleading_and moving and beautiful language. The burden of its supplication was, that an ever-merciful and benignant Father of us all would watch over our noble young soldiers, and aid, comfort, and encourage them in their patriotic work; bless them, shield them in the day of battle and the hour of peril, bear them in His mighty hand, make them strong and confident, invincible in the bloody onset; help them to crush the foe, grant to them and to their flag and country imperishable honor and glory - [Zwick 1992].

At this point in the service an aged stranger intervenes. Motioning to the minister to step aside, he announces that he has been sent from God, who has commanded him to put into words the unspoken part of the long prayer:

[4] "O Lord our Father, our young patriots, idols of our hearts, go forth to battle be Thou near them! With them - in spirit - we also go forth from the sweet peace of our beloved firesides to smite the foe. O Lord our God, help us to tear their soldiers to bloody shreds with our shells; help us to cover their smiling fields with the pale forms of their patriot dead; help us to drown the thunder of the guns with the shrieks of their wounded, writhing in pain; help us to lay waste their humble homes with a hurricane of fire; help us to wring the hearts of their unoffending widows with unavailing grief; help us to turn them out roofless with little children to wander unfriended the wastes of their desolated land in rags and hunger and thirst, sports of the sun flames of summer and the icy winds of winter, broken in spirit, worn with travail, imploring Thee for the refuge of the grave and denied it for our sakes who adore Thee, Lord, blast their hopes, blight their lives, protract their bitter pilgrimage, make heavy their steps, water their way with their tears, stain the white snow with the blood of their wounded feet! We ask it, in the spirit of love, of Him Who is the Source of Love, and Who is the ever-faithful refuge and friend of all that are sore beset and seek His aid with humble and contrite hearts. Amen." [Zwick 1992]

Ideationally speaking, what is unspoken is of course the cost of victory for the defeated. Twain's elaboration of this cost is outlined in Table 3 below. As with text [2] above, the elaboration involves action processes 
impacting on the 'enemy' and their families. Several of these are metaphorical, and have the effect of further intensifying the devastation and suffering which the stranger notes has to victory ("cannot help but follow it").

Table 3: Materialisation of victory in the War Prayer

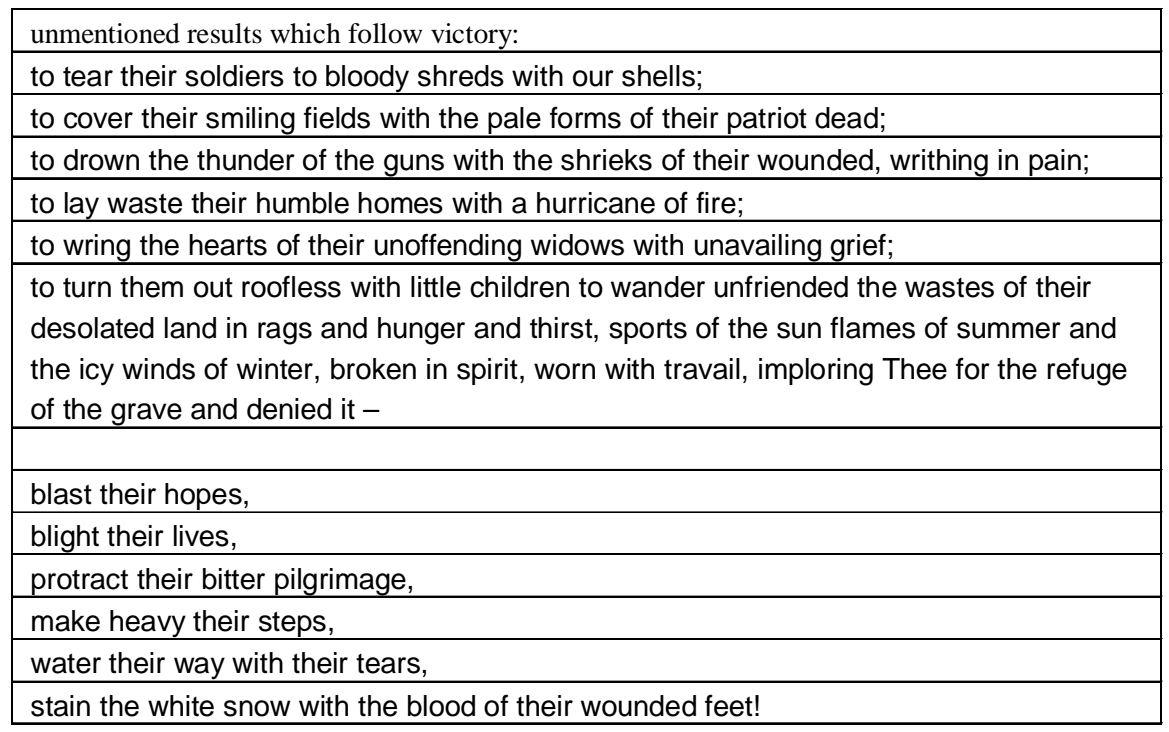

As Table 3 presents these materialisations of victory, they fall into two groups - corresponding to the two major supplications of the prayer. The first asks for God's help (belp us to tear... x6), the second for his direct intervention (blight their hopes... $\mathrm{x} 6$ again); the opening supplication is shorter and milder, asking God to be near 'our' soldiers. The prayer closes by beseeching in the name of love. Information distribution ${ }^{7}$ in the text highlights these patterns, as outlined in Table 4 below. The three supplications open with an interpersonal Theme (a vocative) addressing God, and develop ideationally through processes of destruction; News elaborate the bitter harvest of God's prospective intervention.

\footnotetext{
The periodicity analysis here follows Martin \& Rose 2003, which allows for unmarked Themes following marked Themes; Predicators (e.g. help... to tear or blast) are taken as unmarked Themes in imperatives.
} 
Table 4: Information flow in Twain's War Prayer

\begin{tabular}{|c|c|}
\hline $\begin{array}{l}\text { Theme - (marked) \& } \\
\text { unmarked; } \\
\text { vocative Themes in } \\
\text { sand font }\end{array}$ & (extended) New \\
\hline \multicolumn{2}{|l|}{ O Lord our Father, } \\
\hline $\begin{array}{l}\text { our young patriots, } \\
\text { idols of our hearts, }\end{array}$ & (go forth) to battle -- \\
\hline be & (Thou) near them! \\
\hline \multirow[t]{2}{*}{$\begin{array}{l}\text { (With them -- in spirit) } \\
-- \text { we }\end{array}$} & (also go forth) from the sweet peace of our beloved firesides \\
\hline & (to smite) the foe. \\
\hline \multicolumn{2}{|l|}{ O Lord our God, ${ }^{8}$} \\
\hline help...to tear & (us... their soldiers to bloody shreds) with our shells; \\
\hline help...to cover & $\begin{array}{l}\text { (us ... their smiling fields) with the pale forms of their patriot } \\
\text { dead; }\end{array}$ \\
\hline \multirow[t]{2}{*}{ help...to drown } & (us ... the thunder of the guns) with the shrieks of their wounded, \\
\hline & writhing in pain; \\
\hline help...to lay waste & (us ... their humble homes) with a hurricane of fire; \\
\hline help...to wring & $\begin{array}{l}\text { (us ... the hearts of their unoffending widows) with unavailing } \\
\text { grief; }\end{array}$ \\
\hline \multirow[t]{7}{*}{ help...to turn } & (us ... them out roofless) with little children \\
\hline & $\begin{array}{l}\text { (to wander unfriended the wastes of their desolated land) in rags } \\
\text { and hunger and thirst, }\end{array}$ \\
\hline & sports of the sun flames of summer and the icy winds of winter, \\
\hline & (broken) in spirit, \\
\hline & (worn) with travail, \\
\hline & (imploring Thee) for the refuge of the grave \\
\hline & and denied it - \\
\hline \multicolumn{2}{|l|}{$\begin{array}{l}\text { (for our sakes who } \\
\text { adore Thee), Lord, }\end{array}$} \\
\hline blast & their hopes, \\
\hline blight & their lives, \\
\hline protract & their bitter pilgrimage, \\
\hline make & heavy their steps, \\
\hline water & their way with their tears, \\
\hline stein & the white snow with the blood of their wounded feet! \\
\hline We & $\begin{array}{l}\text { ask it, in the spirit of love, of Him Who is the Source of Love, and } \\
\text { Who is the ever-faithful refuge and friend of all that are sore } \\
\text { beset and seek His aid with humble and contrite hearts. }\end{array}$ \\
\hline
\end{tabular}

Moving up a wavelength as far as periodicity is concerned, we can take the first short supplication sentence as a hyper-Theme, generalising what will follow ('be near our soldiers as they smite the foe'), and the concluding 'asking in the name of love' sentence as a hyper-New, sarcastically consolidating what has been requested.

8 This interpersonal Theme, like Lord in the second major supplication, functions as a Vocative for the whole of the clause complex which follows, so has been laid out on a separate line here. 
[4'] Hyper-Theme "O Lord our Father, our young patriots, idols of our hearts, go forth to battle - be Thou near them! With them - in spirit - we also go forth from the sweet peace of our beloved firesides to smite the foe.

O Lord our God, help us to tear their soldiers to bloody shreds with our shells; help us to cover their smiling fields with the pale forms of their patriot dead; help us to drown the thunder of the guns with the shrieks of their wounded, writhing in pain; help us to lay waste their humble homes with a hurricane of fire; help us to wring the hearts of their unoffending widows with unavailing grief; help us to turn them out roofless with little children to wander unfriended the wastes of their desolated land in rags and hunger and thirst, sports of the sun flames of summer and the icy winds of winter, broken in spirit, worn with travail, imploring Thee for the refuge of the grave and denied it - for our sakes who adore Thee, Lord, blast their hopes, blight their lives, protract their bitter pilgrimage, make heavy their steps, water their way with their tears, stain the white snow with the blood of their wounded feet!

We ask it, in the spirit of love, of Him Who is the Source of Love, and Who is the ever-faithful refuge and friend of all that are sore beset and seek His aid with humble and contrite hearts. Amen." Hyper-New

Moving up a stratum, from information flow (discourse semantics) to field (register), one is struck by the counterpointing of Christian love and demonic brutality. Both Hyper-Theme and Hyper-New sounds overwhelmingly like charitable Christian prayers; this is reinforced by the method of development of the first major supplication ( $O$ Lord our God, belp us...), and the beginning of the second (for our sakes who adore Thee, lord). But the field shifts dramatically in each clause of the two major supplications, as Twain focuses our attention on the victims of war. There's nothing charitable about their fate, the unspoken part of the minister's long prayer. This to and fro of registers is outlined in table 5 below.

Reinforcing these field shifts are the appraisal resources aligning readers. Christian charity is associated as we might expect with positive values inscribing 9 love, friendship, peace, faith, humility and contrition:

\footnotetext{
9 The terms 'inscribe', 'provoke' and 'flag' are being used technically here, following Martin \& White 2005 - inscribe for explicitly evaluative lexis (e.g. humble), provoke for lexical metaphors (e.g. a hurricane of fire) and flag for intensified lexis (e.g. desolated, imploring).
} 
Table 5: Christian love vs demonic brutality in Twain's War Prayer

\begin{tabular}{|c|c|}
\hline Christian love (sacred) & demonic brutality (profane) \\
\hline $\begin{array}{l}\text { O Lord our Father, our young } \\
\text { patriots, idols of our hearts, go } \\
\text { forth to battle -- be Thou near } \\
\text { them! With them -- in spirit -- } \\
\text { we also go forth from the } \\
\text { sweet peace of our beloved } \\
\text { firesides }\end{array}$ & to smite the foe. \\
\hline \multicolumn{2}{|l|}{ O Lord our God, } \\
\hline help us & $\begin{array}{l}\text { to tear their soldiers to bloody shreds with our } \\
\text { shells; }\end{array}$ \\
\hline help us & $\begin{array}{l}\text { to cover their smiling fields with the pale forms of } \\
\text { their patriot dead; }\end{array}$ \\
\hline help us & $\begin{array}{l}\text { to drown the thunder of the guns with the shrieks of } \\
\text { their wounded, writhing in pain; }\end{array}$ \\
\hline help us & $\begin{array}{l}\text { to lay waste their humble homes with a hurricane of } \\
\text { fire; }\end{array}$ \\
\hline help us & $\begin{array}{l}\text { to wring the hearts of their unoffending widows with } \\
\text { unavailing grief; }\end{array}$ \\
\hline help us & $\begin{array}{l}\text { to turn them out roofless with little children to } \\
\text { wander unfriended the wastes of their desolated } \\
\text { land in rags and hunger and thirst, sports of the sun } \\
\text { flames of summer and the icy winds of winter, } \\
\text { broken in spirit, worn with travail, imploring Thee for } \\
\text { the refuge of the grave and denied it - }\end{array}$ \\
\hline \multirow[t]{6}{*}{$\begin{array}{l}\text { for our sakes who adore } \\
\text { Thee, Lord, }\end{array}$} & blast their hopes, \\
\hline & blight their lives, \\
\hline & protract their bitter pilgrimage, \\
\hline & make heavy their steps, \\
\hline & water their way with their tears, \\
\hline & $\begin{array}{l}\text { stain the white snow with the blood of their } \\
\text { wounded feet! }\end{array}$ \\
\hline $\begin{array}{l}\text { We ask it, in the spirit of love, } \\
\text { of Him Who is the Source of } \\
\text { Love, and Who is the ever- } \\
\text { faithful refuge and friend of all } \\
\text { that are [sore beset] and seek } \\
\text { His aid with humble and } \\
\text { contrite hearts. Amen. }\end{array}$ & \\
\hline
\end{tabular}


young patriots

idols of our hearts

the peace of our beloved firesides

the spirit of love

the Source of Love

ever-faithful refuge and friend

humble and contrite hearts

Turning to the cost of war, its victims are explicitly evaluated as innocent:

smiling fields

humble homes

unoffending widows

Intensification, involving highly charged non-core lexis, is used to flag negative evaluations of the war's material consequences:

tear... to bloody shreds

the wastes of their desolated land

imploring

blast

blight

protract

Alongside this lexical metaphor is used to provoke negative reactions (basically aligning the trials of war not everyone experiences with the afflictions of nature most people have):

drown the thunder of the guns

a hurricane of fire

to wring the hearts of their unoffending widows

sports of the sun flames of summer and the icy winds of winter

the refuge of the grave

water their way with their tears

stain the white snow with the blood of their wounded feet

Note that Twain's stranger uses explicit inscriptions of positive attitude in relation to Christian charity, but relies on intensification and lexical metaphor to invoke negative readings of the effects of war. The complementarity avoids the problem of praising then criticising his audience 
in a single breath, and rhetorically speaking has a subversive effect, first bonding with readers, and then giving them something to think about without being overly didactic about what they are meant to feel.

Of course Twain's overall position is clear. His literary profile positions him as a well-known satirist. And in case uneducated readers don't know how satire ${ }^{10}$ works, his stranger pretty much spells it out for them in his introduction to the prayer:

"I come from the Throne - bearing a message from Almighty God! ... He has heard the prayer of His servant your shepherd, and will grant it if such shall be your desire after I, His messenger, shall have explained to you its import - that is to say, its full import. For it is like unto many of the prayers of men, in that it asks for more than he who utters it is aware of - except he pause and think.

"God's servant and yours has prayed his prayer. Has he paused and taken thought? Is it one prayer? No, it is two - one uttered, the other not. Both have reached the ear of Him Who heareth all supplications, the spoken and the unspoken. Ponder this - keep it in mind. If you would beseech a blessing upon yourself, beware! lest without intent you invoke a curse upon a neighbor at the same time. If you pray for the blessing of rain upon your crop which needs it, by that act you are possibly praying for a curse upon some neighbor's crop which may not need rain and can be injured by it.

"You have heard your servant's prayer - the uttered part of it. I am commissioned of God to put into words the other part of it - that part which the pastor - and also you in your hearts - fervently prayed silently. And ignorantly and unthinkingly? God grant that it was so! ... When you have prayed for victory you have prayed for many unmentioned results which follow victory - must follow it, cannot help but follow it. Upon the listening spirit of God fell also the unspoken part of the prayer. He commandeth me to put it into words.

In hindsight, Twain's explanation of his rhetoric may seem heavyhanded. But protesting against war is a delicate issue, inviting accusations of cowardice and lack of patriotism, and risking charges of disloyalty, even treason. Beyond this, Twain is treating the mainstream religion of his day with great irreverence - lampooning ministers and their congregations, and inserting a demonic parody of Christian prayer. The cloak of humour lets Twain say things he couldn't otherwise say; but he has to make sure

10 Throughout, I have tried to use the literary terms satire, irony, sarcasm, caricature and lampoon in the sense of Abrams 1965; there is an urgent need for functional linguistics to re-appraise this field of inquiry, in relation to recent developments in appraisal theory and its desperate need for a theory of humour. 
readers will recognise the genre as satirical - i.e. as amusing on the surface but as deadly serious underneath. Twain further covers himself in closing by offering readers a dismissive reading of the stranger's prayer: "It was believed afterward that the man was a lunatic, because there was no sense in what he said." We have to keep in mind at this point that none of this rendered Twain's story publishable in 1905 as a critique of burgeoning American imperialism; it took Twain's death and the context of a war amongst European imperial powers for posthumous publication to be possible.

\section{Raymond Briggs \& La Guerra de las Malvinas}

Let's return now to the end of the English empire, moving from the troubles in Ireland to the Malvinas War, fought off the coast of Argentina after they took control of the islands in 1982. Britain's victory in this conflict is generally read as having discredited the military dictatorship in Argentina, leading to its downfall and a return to democracy in 1983; for Prime Minister Margaret Thatcher the victory is generally credited with having resurrected her sagging political career. Argentina lost 655 men killed in the fighting and Britain 236, alongside large numbers of wounded. Responding to the nationalist celebration of victory in Britain, Raymond Briggs published a children's story entitled The Tin Pot General and the Old Iron Woman, in 1984. Briggs is a well-known author and illustrator of children's books, although this publication departs radically from his usual comic book style - assuming a more traditional words and pictures approach (i.e. one illustration and a sentence or two per double page).

Brigg's verbal text is reproduced as text $[5]$ below, using double slashes to separate text on the left hand page of a two-page spread from that in the right, and triple slashes separating two-page spreads from one another (a 'turn the page signal' in other words).

[5] Once upon a time, down at the bottom of the world, there was a sad little island. /// No one lived on the sad little island except for a few poor shepherds. These poor shepherds spend all their time // counting their sheep and eating them. They had mutton for breakfast, mutton for dinner and mutton for tea. /// Next door to the sad little island was a great big kingdom, ruled over by a Wicked Foreign General. // This Wicked Foreign General has wicked foreign moustachois, and although he had lots of gold on his hat, he was not real. He was made of Tin Pots. /// Now, this Tin- 
Pot Foreign General wanted to be Important. He wanted to do something Historical, so that his name would be printed in all the big History Books. // So, one day, he got all his soldiers and all his guns and he put them into boats. Then he sailed them over the sea to the sad little island. // There he stamped ashore and bagsied the sad little island for her very own. // "Mea baggazza el islandio!" ("I bags the island!) he roared. /// The poor shepherds did not like this at all, because the Tin-Pot Foreign General started bossing them about. /// Now listen! Far away over the sea there lived an old woman with lots of money and guns. // Like the Tin-Pot Foreign General she was not real, either. She was made of iron. /// When this Old Iron Woman heard that the Tin-Pot Foreign general had bagsied the sad little island, she flew into a rage. // "It's MINE!" she screeched. "MINE! MINE! MINE! I bagsied it AGES ago! I bagsied it FIRST! DID! DID! DID!” // She poured out tons of treasure from her huge chest and bought lots and lots of boats. // Then she got all her soldiers and guns and she put them into the boats and sailed them over the sea to the sad little island. // She wanted to bagsy the sad little island back again, you see. /// BANG! BANG! BANG! went the guns of the Tin-Pot Foreign General. // BANG! BANG! BANG! went the guns of the Old Iron Woman. /// Some men were shot. /// Some men were drowned. /// Some men were burned alive. /// Some men were blown to bits. /// Some men were only half blown to bits and came home with parts of their bodies missing. /// Hundreds of brave men were killed. And they // were all real men, made of flesh and blood. They were not made of Tin or Iron. / // In the end, the Old Iron Woman's soldiers beat the Tin-Pot Foreign General's soldiers and the Tin-Pot Foreign General's soldiers ran away. "I WON!" sang the Old Iron Woman. "REJOICE!" "Mei villi ritorno!" (I will return!) swore the TinPot Foreign General. /// So the poor shepherds on the sad little island went on counting their sheep and eating them. They had mutton for breakfast, mutton for dinner // and mutton for tea. Three of them were killed in the battle, but no one was to blame /// Later on, a boat came back to the Old Iron Woman's // kingdom with a big iron box full of dead bodies. /// Then the Old Iron Woman gave all her soldiers // a special medal. /// After this, there was a Grand Parade to celebrate the Great // Victory and everyone went to Church and Thanked God. /// But the soldiers with the bits of their bodies missing were not invited to take part in the Grand Parade, in case the sight of them spoiled the rejoicing. Some watched from a grandstand and others stayed at home with their memories and their medals. // And the families of the dead tended the graves. [Briggs 1984]

Although presented generically as a bed-time story for children, Brigg's book gives fair warning of his political intent - beginning as it does with two quotes on the left-hand page facing its opening:

Nationalism is an infantile disease. It is the measles of mankind. ALBERT EINSTEIN

Patriotism is the last refuge of a scoundrel. DR. JOHNSON 
Verbally, the story itself unfolds as a contextual metaphor - a bedtime story standing for a historical recount of the Malvinas War. For the first part of the story the illustrations involve caricatures, of the 'shepherds' on the island (dressed in monks habit), a gigantic General Galtieri, his ships and soldiers (as toy boats and soldiers) and a gigantic Margaret Thatcher, her money and guns, and ships (also toys, with Thatcher as a dominatrix, dressed only in stockings and high heels). The greyscale of Galtieri and Thatcher's bodies is complemented by splashes of bold warm colour highlighting various symbolic attributes of each protagonist (weapons and markers of rank for Galtieri; money, hair and breast milk ${ }^{11}$ for Thatcher). These illustrations construe a world of playful fantasy, including sexual fantasy; a more mundane verbal text below renders the events of history simply in story-book language for young children. The sexual imagery is outrageous, in my experience fascinating young readers (who giggle in response), and amusing mature readers who appreciate the caricature (who laugh heartily).

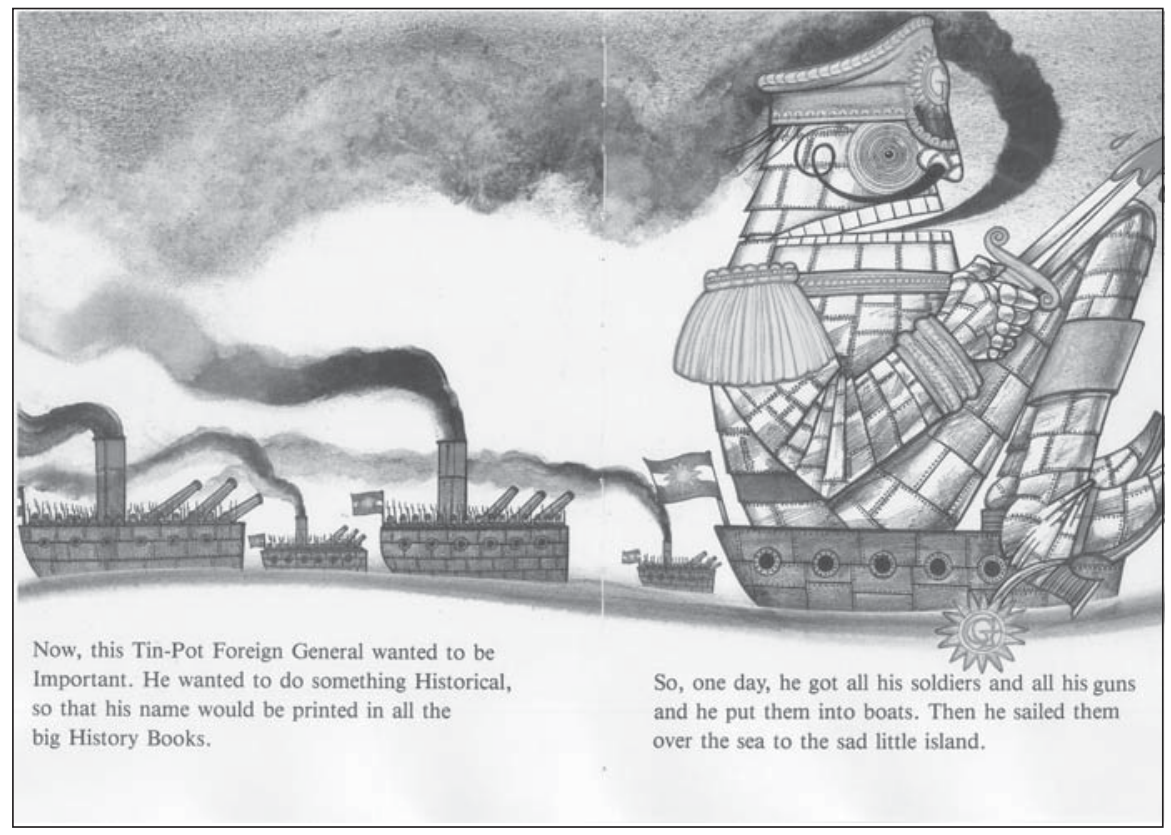

11 Thatcher's breasts, which have cannon nipples, spew smoke as she explodes in rage over the Tin Pot General's occupation of 'her' island. 


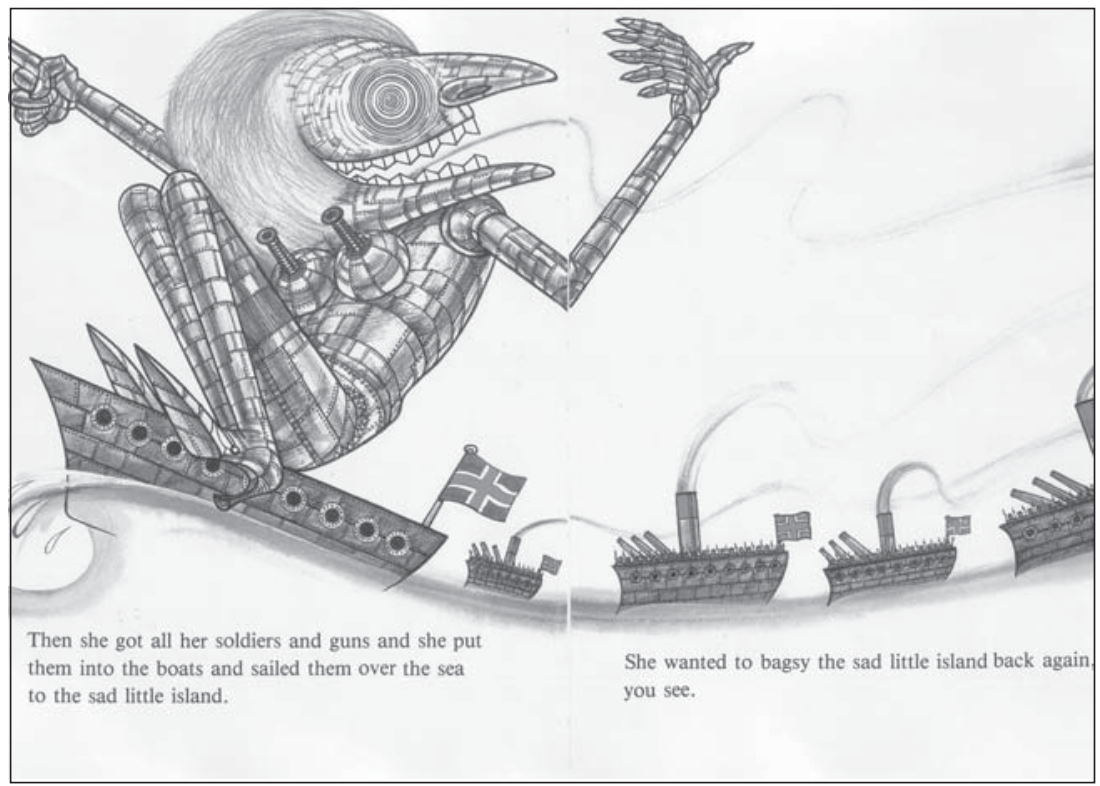

This opening phase of the story contrasts sharply with phase two, immediately following the 'Bang, bang, bang' verbal text. The verbiage moves to the left-hand page (Some men were shot...), and the illustrations to the right; and the colourful toy caricatures are replaced by greyscale etchings of dead soldiers. The illustrations clearly represent real men, not toys, but involve minimal attribution, and no circumstantiation. This has the effect of generalising the soldiers' fate as applicable to any man, and avoiding a sensationalised representation of the physical ghastliness of their deaths.

Some men were shot

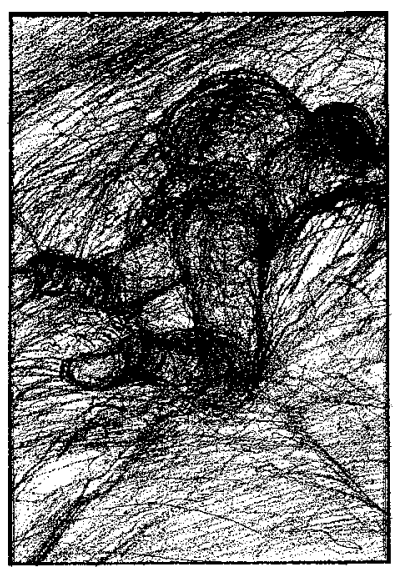


As we move from phase 1 to phase 2 of the story then, fantasy gives way abruptly to reality - profane colour paintings are replaced by evocative greyscale etchings, and the satirical bed-time story is replaced by hard news reporting. This dramatic shift of semiotic gears is outlined in Table 6 below.

Table 6: Moving from fantasy to reality in Brigg's story

\begin{tabular}{|l|l|l|}
\hline & PHASE 1 - FANTASY & PHASE 2 - REALITY \\
\hline IMAGE & $\begin{array}{l}\text { toy caricatures above: } \\
\text { Galtieri (metal moustached general) } \\
\text { Thatcher (metal dominatrix) } \\
\text { toy } \\
\text { boats/soldiers/ships/weapons/mone } \\
\text { y... }\end{array}$ & etchings right: \\
greyscale images of dead soldiers \\
\hline VERBIAGE & $\begin{array}{l}\text { Once upon a time, sad little island, } \\
\text { few poor shepherds, wicked foreign } \\
\text { general, Now listen!, far away over } \\
\text { the sea there lived an old woman, } \\
\text { BANG! BANG! BANG! went the } \\
\text { guns ... }\end{array}$ & $\begin{array}{l}\text { Some men were shot. Some men } \\
\text { were drowned. Some men were } \\
\text { burned alive. Some men were } \\
\text { blown to bits. }\end{array}$ \\
\hline
\end{tabular}

This phase of the story closes with two double page spreads, with image above verbiage, which further materialise the cost of war. Some men were only balf blown to bits... is accompanied by a greyscale etching of an indefinitely large group of wounded men above, with just enough attribution in the front row or two for us to recognise their maiming. Hundreds of real men were killed... is illustrated with a very cool dim graveyard containing row upon row of crosses converging endlessly into the background. High valued quantification ${ }^{12}$ is used to flag the horror of what went on (a throng of wounded soldiers and innumerable graves in the images; numerical quantification, bundreds of, in the verbiage).

As far as the experiential materialisation of war is concerned then, where Bono and Twain move from abstractions to reality, Briggs moves from make-believe to real - from playing at war with toy soldiers to the realities of war for real men. In contemporary terms this might well be read as a critique of virtual computer-game wars we watch from a distance on $\mathrm{TV}$, in contrast to the visceral slaughtering we might experience on the ground (and the coffins we not allowed to see arriving home).

12 The analysis of graduation resources used here is summarised in Hood \& Martin 2006. 
The third phase of the story, beginning In he end..., deals with the aftermath of the conflict, principally for Britain. Verbally, we return to the bed-time story language of phase 1 (...the Tin-Pot Foreign General's soldiers ran away... "I WON!" sang the Old Iron Woman... So the poor shepherds on the sad little island... etc). The initial image accompanying the victory proclamation involves a large, even more colourful caricature of Thatcher, dominating a smaller muted and disintegrating caricature of Galtieri. And this is followed by a cool dim illustration of the wreckage and debris of war on the island. Subsequently the nature of the illustrations splits - greyscale etchings for the victims of war (a container of dead bodies arriving home, an amputee and his family at home, a family tending the grave of a dead relative), and bold colour for the symbolic attributes of victory (the special medal's ribbon, British flags at the parade, Thatcher's face on TV). This sets up a disjunction between fantasy and reality (colourful symbols of glory vs greyscale death and injury in images) which disturbs the victory celebration naturalised in western media around the world.

As far as appraisal is concerned, the picture is similarly discordant. Briggs inscribes the populist evaluations of nationalist sentiment: joy in victory ("REJOICE13!", to celebrate, Thanked God, the rejoicing), sympathy for the inhabitants of the Malvinas (the poor shepherds, the sad little island), alsolution for those inflicting 'collateral damage' (but no one was to blame), appreciation of victory (a special medal, a Grand Parade, the Great Victory) and distaste for the maimed (in case the sight of them spoiled the rejoicing). This alignment sits uneasily with the horror of war materialised in phase 2 of the story, where Briggs has made clear how he feels about what went on.

Hundreds of brave men were killed. And they // were all real men, made of flesh and blood. They were not made of Tin or Iron. ///

And it sits just as uneasily with the exclusion of casualties and their families from the parade in phase 3:

But the soldiers with the bits of their bodies missing were not invited to take part in the Grand Parade, in case the sight of them spoiled the rejoicing. Some watched from a grandstand and others stayed at home with their memories and their medals. And the families of the dead tended the graves.

13 Items in bold are affect, underlined are appreciations and highlighted are judjement. 
In case we are in any doubt about who we're meant to side with in this play of voices, interpersonal dimensions of Briggs' images guide us. Towards the end of phase 2, readers have been positioned level and in eye contact with the group of maimed soldiers noted above, the only engagement of this kind in the book (elsewhere we view consistently in an observer role, except for one episode of eye contact with Galtieri, which is however from a viewing position far below him).

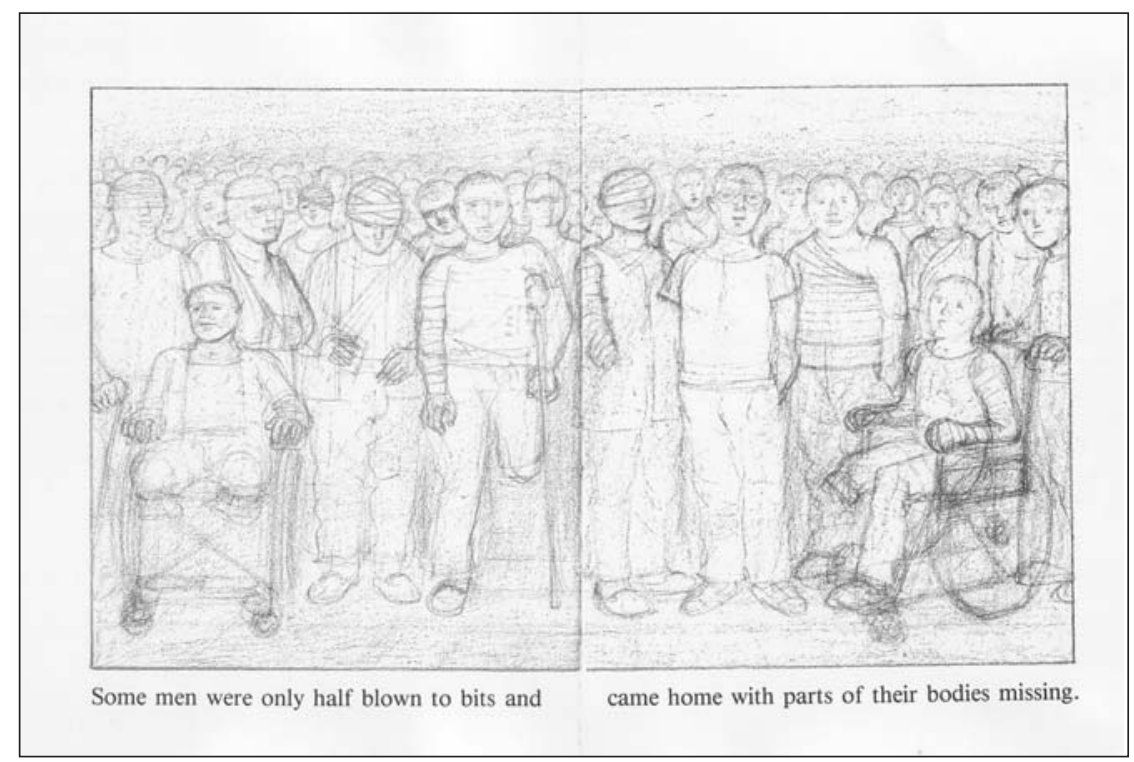

Later, at the close of phase 3, we are positioned as participants in the Grand Parade, looking up at dominating flags and a church spire. In the next image, we look down and over the left shoulders of the amputee and his family so that vicariously we watch Thatcher's caricature on TV (with them as it were). Then finally we stand level with two adults and a child, behind them mourning at the grave. The trajectory of viewing positions is clearly designed to move us from celebration of victory to sympathy for the injured and then empathy with the families of the dead. Ambience shifts in harmony with this move, from bold warm mixed with cool colour at the parade, to greyscale etching with just a splash of bold warm colour on TV in the amputee's home, to simply greyscale etching in the cemetery.

The only way to ultimately resolve the discordant voices is to read the inscribed populist evaluations in phase 3 as ironic, since the reading position 
Brigg's is naturalising through his words and images taken as a whole is opposed to that literally expressed in the verbiage. Reasoning along these lines we can characterise Brigg's rhetoric as subversive; he gives voice to patriotism, at the same time lampooning it with colourful caricatures and childish bed-time story discourse, and confronting it with stark etchings and his grim attitude-invoking reportage of generally unspoken news.

\section{Rhetorics of opposition: materialisation and re-alignment}

As noted in section 1 above, these three anti-war discourses each feature ideational features which reformulate legitimations of war as matters of flesh and blood, and interpersonal features which negotiate alternative evaluations of the cost of war. Ideationally speaking, each text spells out in actions processes the material consequences of armed conflict. For Bono and Twain this involves unpacking nominalisations, in a manner strikingly parallel to the deconstruction strategy pioneered for CDA by Trew (1979) for media discourse. Briggs works towards consequences in another direction, since he is reworking his bedtime story parody of war as play into the physical and personal realities involved. These movements from unreal to real are summarised in Table 7 below.

Table 7: Ideational reconstrual in 3 anti-war texts

\begin{tabular}{|l|l|l|}
\hline & Unreal & to Real \\
\hline U2 (Bono) & revolution & $\begin{array}{l}\text {.. To leave them dying or crippled for life or } \\
\text { dead under the rubble... }\end{array}$ \\
\hline Twain & victory & $\begin{array}{l}\text {..to drown the thunder of the guns with the } \\
\text { shrieks of their wounded, writhing... }\end{array}$ \\
\hline Briggs & Bang! Bang! Bang! & $\begin{array}{l}\text {... Hundreds of brave men were killed... all real } \\
\text { men, made of flesh and blood... }\end{array}$ \\
\hline
\end{tabular}

Interpersonally speaking, each text attempts to re-position people naturalised by war legitimating spin into membership in pro-war communities. Bono takes glorification of the Irish republican revolution and uses appraisal, speech function and mood to make over his audience as a group which is revolted by violence and screams in unison for an end to terror. Twain develops a parody of prayer by turning Christian supplication into Satanic imprecation - using appraisal to contrast positive inscriptions of charity with negative evocations of horror, line by line; the humour of 
his satire is designed to both amuse his readership and license his intervention, irreverently sacrilegious though it might be read to be. Briggs also uses humour ${ }^{14}$ to make room for his anti-nationalist sentiments, and to bond with reader/viewers amused by his caricatures and parody of the bed-time story genre. His words and images are then re-deployed to shock them back into reality, and re-align them with the victims of war. These interpersonal negotiation strategies are summarised in table 8 below.

Table 8: Interpersonal realignment in 3 anti-war texts

\begin{tabular}{|l|l|l|}
\hline & Initial bonding & Subsequent positioning \\
\hline Bono (U2) & glorify the revolution & negotiate revulsion of terror \\
\hline Twain & Christian supplication & Satanic imprecation \\
\hline Briggs & caricature of leaders & empathy for victims \\
\hline
\end{tabular}

The impact of these re-contextualisation and re-alignment manoeuvres is in each text enhanced by the disjunctive texture through which they unfold. Bono moves stridently from his slow lamenting ballad to his angry sermon on his 'pulpit' left of stage; and within his rap he switches from relatively introverted evaluative monologue to his interactively embodied call and response chant. Twain moves from his satirical recount of the church service to his stranger's prayer, within which Christian charity and demonic barbarity are brought into direct opposition to one another. Briggs involves us in his verbally amusing and pictorially outrageous bed-time story, setting us up for a shocking confrontation ${ }^{15}$ with the realities of the war we've just been laughing at. These engagements are summarised below:

U2(Bono) $\quad$ song $\rightarrow$ rap $\{$ glorification $\rightarrow$ revulsion $\{$ monologue $\rightarrow$ dialogue $\}$ \} Twain $\quad$ recount $\rightarrow$ prayer $\{$ supplication $\rightarrow$ imprecation $\}$

Briggs children's story/caricature $\rightarrow$ untold history/everyman

\footnotetext{
14 Note that for both Twain and Briggs, deploying humour helps to widen their audience; as a famous and charismatic rock ' $\mathrm{n}$ roll star with a next to captive audience, Bono doesn't have to be funny to enact a mass appeal.

15 The drama of Brigg's shift in gears can be usefully explored by getting a first-time reader to read the text aloud to a naive audience; inevitably laughter gives way abruptly to an embarrassed silence, leaving people uncomfortable about the way they have been 'tricked' by the text.
} 
In real terms, what have these texts achieved? Does Bono's chant simply reflect the power of his multimodal moment ${ }^{16}$ and the adoration of his fans? Or are we looking at an important vehicle for social change enacted by influential musicians throughout the 20th century, ever more so perhaps as electronic media construct mass markets for their songs (think Live Aid, 'Give Peace a Chance', 'The Times they are a Changing', 'This Land is your Land', 'Strange Fruit' and so on down the line)? Does the late publication of Twain's prayer mean that media censorship, both selfcensorship and governmental control, will carefully suppress texts that threaten the status quo? Or should we evaluate Twain's intervention in the context of the freedom of expression principles enabling the publicity generated by the Anti-Imperialist League, America's former reluctance to get involved in European wars, and the anti-war movements in relation to Vietnam and Iraq? Should we dismiss Brigg's irreverent co-option of the picture book genre as passing over the heads of child readers and simply preaching to the converted as far as their parents are concerned? Or is this simply a childist dismissal of a site where young readers, parents and teachers can explore morality in an apparently increasingly secular and materialist world?

I don't know the answer to these questions. But more importantly, the obsession of 20th century scholarship with critique, alongside the relative absence of concern with how people improve their world, mean that nobody else seems to know the answer either. Fortunately, this scholarly vacuum hasn't stopped activists from working hard to give peace a chance. Why not find out how they go about it, what seems to work, and give them a hand?

Recebido em janeiro de 2006 Aprovado em fevereiro de 2006 E-mail: jmartin@mail.usyd.edu.au

16 The fact that Bruce Springsteen can get almost anyone to stand up at a concert, raise their right arm, clench a fist and sing Born in the USA gives one pause (although this does involve everyone who does so in a protest song on behalf of veterans of the Vietnam War). 


\section{REFERENCES}

Abrams, M. H. 1965. A Glosary of Literary Terms. New York: Holt, Rinehart \& Winston.

Bloomfield, L. 1917. Tagalog Texts with Grammatical Analysis. Part 1: Texts and translation. Part 2: Grammatical analysis. (University of Illinois Studies in Language and Literature $2 \& 3$ ) Urbana: University of Illinois. BrIGgs, R. 1984. The Tin-Pot Foreign General and the Old Iron Woman. London: Hamish Hamilton.

Cranny-Francis, A. \& J. R. Martin. 1991. Contratextuality: the poetics of subversion. F Christie [Ed.] Literacy in Social Processes: papers from the inaugural Australian Systemic Linguistics Conference, beld at Deakin University, January 1990. Darwin: Centre for Studies in Language in Education, Northern Territory University. 286-344.

EdWARDS, J. \& J. R. MARTIN [Eds.] 2004. Interpreting Tragedy: the language of September 11 ${ }^{\text {th, }}, 2001$ (Special Issue of Discourse E Society 15.2/3).

GandarA, L. 2004. 'They that sow the wind...': proverbs and sayings in argumentation. Discourse \& Society 15.2-3. 345-359.

Halliday, M. A. K. \& C. M. I. M. Matthiessen 2004. An Introduction to Functional Grammar. (3rd Edition) London: Arnold.

HoOD, S. \& J. R. MARTIN 2006. Invoking attitude: the play of graduation in appraising discourse. R. Hasan, C. M. I. M. Matthiessen \& J. Webster [Eds.] Continuing Discourse on Language. London: Equinox. in press for 2006. [Spanish translation Revista Signos 2005]

KRESS, G. \& T. vAN LEEUwEN 1996. Reading Images: the grammar of visual design. London: Routledge.

Martin, J. R. 1992. English Text: system and structure. Amsterdam: Benjamins.

Martin, J. R. in press Positive discourse analysis: power, solidarity and change. Revista Canaria de Estudios Ingleses.

Martin, J. R. \& D. Rose 2003. Working with Discourse: meaning beyond the clause London: Continuum.

Martin, J. R. \& P. R. R. White 2005. The Language of Evaluation: appraisal in English. London: Palgrave.

Trew, T. 1979. 'What the papers say' R Fowler, B Hodge, G Kress \& T Trew. Language and Control. London: Routledge \& Kegan Paul. 117-156.

U2 1988 Sunday Bloody Sunday. Rattle and Hum. Paramount Pictures. Zwick, J. [Ed.] 1992 Mark Twain's Weapons of Satire. Syracuse: Syracuse University Press. 156-160. 